\title{
IDENTIFICATION OF NITROUS OXIDE GENERATION IN SUBSURFACE WASTEWATER INFILTRATION SYSTEM FILLED WITH MIXED MATRIX
}

\author{
Ying-Hua LI, Lei YANG, Hai-Bo LI, Si-Qi WANG, Fei SU \\ School of Resources and Civil Engineering, Northeastern University, Shenyang, China
}

Received 02 July 2019; accepted 20 January 2020

\begin{abstract}
Subsurface wastewater infiltration systems (SWIS) are one of the important sources of nitrous oxide $\left(\mathrm{N}_{2} \mathrm{O}\right)$ production; understanding the biological processes and contributions of $\mathrm{N}_{2} \mathrm{O}$ will help control the amount of $\mathrm{N}_{2} \mathrm{O}$ produced. To quantitatively reveal the contribution of nitrification and denitrifiaction processes, $8 \mathrm{~g}$ potassium nitrate with 99.99 atom ${ }^{15} \mathrm{~N}$ (i.e. ${ }^{15} \mathrm{~N}$ accounts for $99.99 \%$ of the total $\mathrm{N}$ ) was dissolved in the influent (concentration: $3.3 \mathrm{~g} / \mathrm{L}$ ). Results showed that nitrification released more $\mathrm{N}_{2} \mathrm{O}$ within $0-12 \mathrm{~h}$, accounting for $79.6 \pm 2.4 \%$. The denitrification process accounted for $88.5 \pm 1.3 \%$ for $\mathrm{N}_{2} \mathrm{O}$ generation after the $12^{\text {th }}$ hour. Thus, in order to effectively control the release of $\mathrm{N}_{2} \mathrm{O}$, the denitrification process should be given more attention. The maximum release rate of $\mathrm{N}_{2} \mathrm{O}$ was $8.45 \pm 0.8 \mathrm{mg} / \mathrm{m}^{2} \cdot \mathrm{h}$, which occurred near the end of the first wetting-drying cycle. Since then, peaks appeared periodically, mostly in the "rest" periods.
\end{abstract}

Keywords: subsurface wastewater infiltration, nitrous oxide, generation, domestic sewage, mixed matrix.

\section{Introduction}

Subsurface wastewater infiltration systems (SWIS) offer a promising opportunity to transform municipal wastewater into renewable energy with significantly reduced energy consumption (Pan et al., 2016a; Jiang et al., 2017). Generally, the SWIS process is a soil-based sewage treatment technology. Purification mechanisms involve biological, physical and chemical processes (Li et al., 2017b). The inlet pipe is usually set at a depth of $40-50 \mathrm{~cm}$. The sewage infiltrates the $60-70 \mathrm{~cm}$ support layer under the action of gravity, and then climbs up to a depth of $20-25 \mathrm{~cm}$ driven by capillary force. When gravity is greater than the capillary force, sewage infiltrates into the bottom and is collected. According to the literature (Zhang et al., 2015), aerobic, anoxic and anaerobic states are sequentially dominant from top to bottom, thus the organic matter can be degraded through different biochemical reactions specific to each of those zones(Lloréns et al., 2011).

Although several studies have reported that the SWIS processes can effectively perform nitrogen biotransformation, it has been found to be a source of nitrous oxide $\left(\mathrm{N}_{2} \mathrm{O}\right)$. According to Kong et al. (2002), SWIS emits 3.3$5.0 \mathrm{~g} \mathrm{~N}_{2} \mathrm{O} / \mathrm{m}^{3}$ in China (the total nitrogen concentration was $87 \mathrm{mg} / \mathrm{L}$ ). Furthermore, the aerobic-anaerobic state is closely related to the generation of $\mathrm{N}_{2} \mathrm{O}$. Since then, many researchers expressed their interests in $\mathrm{N}_{2} \mathrm{O}$ generation from the SWIS process. Li et al. (2017b) confirmed via field study that the generation of $\mathrm{N}_{2} \mathrm{O}$ was under the interaction of nitrification and denitrification processes. To solve the problem regarding $\mathrm{N}_{2} \mathrm{O}$ sampling, Li et al. (2018) introduced a layered sampling method. Moreover, many operational parameters affecting $\mathrm{N}_{2} \mathrm{O}$ generation, such as hydraulic load, organic load and intermittent cycle were revealed by Pan et al. (2016b), Jiang et al. (2017), Li et al. (2017a), Li et al. (2018) and Sun et al. (2018). These reports acquainted us with $\mathrm{N}_{2} \mathrm{O}$ generation flux from SWIS. However, the contribution of different biofilm layers and biological processes to the release of $\mathrm{N}_{2} \mathrm{O}$ remains undisclosed.

The isotopic tracer method is a microanalytical method for labeling subjects using radionuclides as tracers. This technology has the advantage of high sensitivity, convenient operation and accurate test results. Moreover, using isotopic techniques, the contribution of nitrification and denitrification processes to $\mathrm{N}_{2} \mathrm{O}$ release was successfully revealed in the Eastern Tropical South Pacific (Ji et al., 2015). Thus, the aim of this paper is to explore our current understanding and knowledge gaps of the role of nitrification and denitrification in $\mathrm{N}_{2} \mathrm{O}$ generation in the SWIS process, and to provide a basis to effectively control the

*Corresponding author. E-mail: graceli_2003@163.com 
release of $\mathrm{N}_{2} \mathrm{O}$ by regulating biological processes. To this end, using isotopic technique, the release rate of $\mathrm{N}_{2} \mathrm{O}$ was presented and discussed according to the calculation of stable $\mathrm{N}$ isotope concentration in the key processes.

\section{Materials and methods}

\subsection{System, substrate and influent quality description}

Four parallel SWIS simulators (plexiglass columns) were constructed, $130 \mathrm{~cm}$ high and $30 \mathrm{~cm}$ in diameter (Figure 1). The inlet pipe was located at a depth of $50 \mathrm{~cm}$ below the soil surface. From top to bottom, each column was filled with farmland soil, mixed matrix and gravel in sequence (Li et al., 2018).

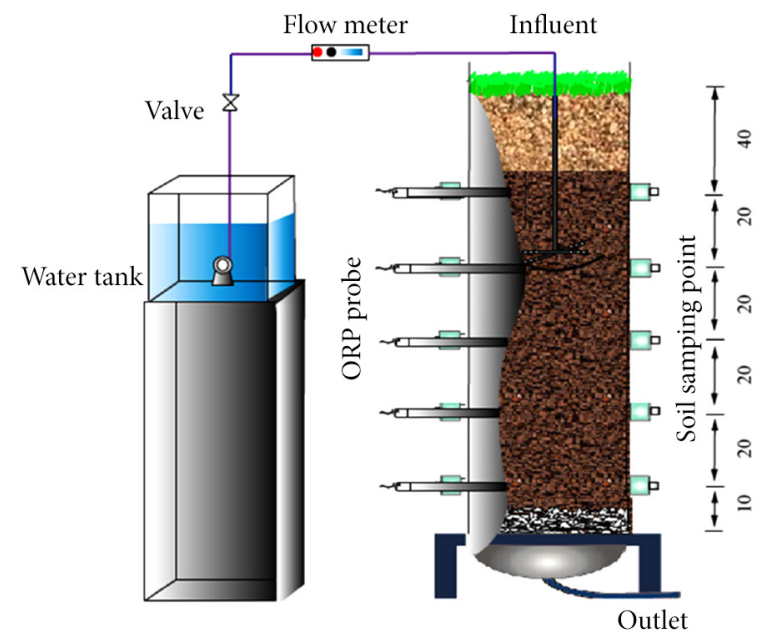

Figure 1. Experimental columns of subsurface wastewater infiltration system

Farmland soil (meadow brown soil, filled in $0-30 \mathrm{~cm}$ ) was sampled from Shenyang Agro-ecosystem Station. Mixed matrix (filled in 30-110 cm) was composed of fine sand (0.1-1.0 $\mathrm{mm}$ in diameter), coal slag $(0.1-0.5 \mathrm{~mm}$ in particle size) and farmland soil mixed in volume ratio of 1:2:7. Gravels (filled in $110-130 \mathrm{~cm}, 1-2 \mathrm{~cm}$ in diameter) were placed at the bottom to support the matrix and minimize the risk of clogging of outlet. A comparison of the properties of meadow brown soil (MBS) and mixed matrix (MM) (Table 1) revealed their substantial differences in porosity and permeability.

Five oxidation reduction potential (ORP) probes (FJA-3) were installed at depths of 40,60, 80, 100 and $120 \mathrm{~cm}$, respectively, giving information on aerobic, facultative and anaerobic conditions. Influent was the blended sewage of campus. The main indexes (Table 2) indicated that the wastewater needed further treatment to meet the discharge standards.

\subsection{Experimental operation}

A flow meter was used to control the influent to $0.09 \pm$ $0.01 \mathrm{~m}^{3} /\left(\mathrm{m}^{2} \cdot \mathrm{d}\right)$. Intermittent operation was adopted with wetting-drying ratio of 1:1 (i.e., SWIS was fed continuously for $12 \mathrm{~h}$ followed by a "rest" period for $12 \mathrm{~h}$ ). During the "rest" period, the system can be reoxygenated (especially for the upper layer), providing conditions that made the biological oxidation of $\mathrm{NH}_{4}{ }^{+}-\mathrm{N}$ and organics possible.

After the effluent quality steadily satisfied the first class A criteria of the "Discharge Standard of Pollutants for Municipal Wastewater Treatment Plant" (GB18918-2002) for 5 consecutive days (GB18918-2002: COD $<50 \mathrm{mg} / \mathrm{L}$, $\mathrm{BOD}_{5}<10 \mathrm{mg} / \mathrm{L}, \mathrm{NH}_{4}{ }^{+}-\mathrm{N}<5 \mathrm{mg} / \mathrm{L}, \mathrm{TN}<15 \mathrm{mg} / \mathrm{L}$ and $\mathrm{TP}<0.5 \mathrm{mg} / \mathrm{L}), 8 \mathrm{~g} \mathrm{~K}^{15} \mathrm{NO}_{3}$ with 99.99 atom $\%{ }^{15} \mathrm{~N}$ was dissolved in influent (concentration: $3.3 \mathrm{~g} / \mathrm{L}$ ) within $2 \mathrm{~h}$. Compared with the added ${ }^{15} \mathrm{~N}$ isotope, the concentration of nitrate in raw water was negligible. Gas samples were taken before the introduction of ${ }^{15} \mathrm{~N}$ isotope and every $60 \mathrm{~min}$ after the addition. At each sampling time, a collection hood $(20 \mathrm{~cm}$ high $)$ was placed on the soil surface for $20 \mathrm{~min}$ and gases were collected using $25-\mathrm{mL}$ plastic syringes. Then the samples were stored in pre-evacuated $20-\mathrm{mL}$ vials and analyzed within $24 \mathrm{~h}$. Influent, effluent and mixed matrix samples were collected and analyzed as well.

\subsection{Analytical method}

Water samples were analyzed according to standard methods (APHA, 2005). $\mathrm{N}_{2} \mathrm{O}$ concentration was determined using a Shimadzu GC-2014 gas chromatograph

Table 1. Comparison of properties between MBS and MM

\begin{tabular}{|c|c|c|c|c|c|c|c|}
\hline \multirow{2}{*}{ Item } & $\mathrm{pH}$ & \multirow{2}{*}{$\begin{array}{c}\text { Organic } \\
\text { matter/ } \\
\%\end{array}$} & \multirow{2}{*}{$\begin{array}{c}\text { Porosity/ } \\
\%\end{array}$} & $\begin{array}{c}\text { Permeability/ } \\
(\mathrm{cm} / \mathrm{s})\end{array}$ & \multicolumn{3}{|c|}{ Granular grading/\% } \\
\cline { 5 - 8 } & & & & & & & \\
\hline MBS & 6.8 & 3.96 & 52.5 & $8.9 \times 10^{-5}$ & 2.0 & 31.1 & 66.9 \\
\hline MM & 7.2 & 4.99 & 56.8 & $1.1 \times 10^{-3}$ & 27.6 & 23.4 & 49.0 \\
\hline
\end{tabular}

Table 2. Main influent quality indexes

\begin{tabular}{|l|c|c|c|}
\hline \multicolumn{1}{|c|}{ Indexes } & $\mathrm{COD} /(\mathrm{mg} / \mathrm{L})$ & $\mathrm{BOD} /(\mathrm{mg} / \mathrm{L})$ & $\mathrm{NH}{ }^{+}-\mathrm{N} /(\mathrm{mg} / \mathrm{L})$ \\
\hline Mean value \pm deviation & $322.2 \pm 9$ & $190 \pm 12$ & $34.7 \pm 9$ \\
\hline Indexes & $\mathrm{NO}_{3}{ }^{-}-\mathrm{N} /(\mathrm{mg} / \mathrm{L})$ & $\mathrm{NO}_{2}{ }^{-}-\mathrm{N} /(\mathrm{mg} / \mathrm{L})$ & $\mathrm{TN} /(\mathrm{mg} / \mathrm{L})$ \\
\hline Mean value \pm deviation & $1.9 \pm 0.1$ & $0.52 \pm 0.1$ & $53.1 \pm 0.2$ \\
\hline
\end{tabular}


manufactured by Shimadzu Corporation (Japan). The detector was a $63 \mathrm{Ni}$ electron capture detector (ECD) and the chromatographic column is an $80 / 100$ mesh Porapak Q packed column. High purity nitrogen (99.999\%) was used as the carrier and back flushing gas at a flow rate of $50 \mathrm{~mL} / \mathrm{min}$. The analysis of ${ }^{15} \mathrm{~N}-\mathrm{N}_{2} \mathrm{O}$ was performed at Stable Isotope Laboratory in Institute of Applied Ecology, Chinese Academy of Sciences (Shenyang, China), determined using a Trace Gas Pre-concentrator and a mass spectrometer (IsoPrime100) (Xi et al., 2016). The water and soil isotopic abundance were determined using a Europa Integra continuous flow isotope ratio mass spectrometer (Europa Scientific, Seron, Cheshire, UK). The analysis was performed in triplicate, and error analysis was carried out by SPSS 18.0.

\subsection{Calculation method}

$\mathrm{N}_{2} \mathrm{O}$ generation rates were estimated using formula (1) (Maucieri et al., 2017):

$$
F_{\mathrm{N}_{2} \mathrm{O}}=H \times\left(C_{2}-C_{1}\right) / \Delta t .
$$

In the above equation, $F_{\mathrm{N}_{2} \mathrm{O}}$ was the generation rate of $\mathrm{N}_{2} \mathrm{O}, \mathrm{mg} /\left(\mathrm{m}^{2} \cdot \mathrm{h}\right) ; H$ was the height of gas collection hood, $\mathrm{m}(0.2 \mathrm{~m}$ here); $\Delta t$ was the time interval between two consecutive sampling, $\mathrm{h} ; C_{1}$ and $C_{2}$ werethe concentration of $\mathrm{N}_{2} \mathrm{O}$ in two consecutive samples, $\mathrm{mg} / \mathrm{m}^{3}$.

${ }^{15} \mathrm{~N}-\mathrm{N}_{2} \mathrm{O}$ generation rate was calculated by formula (2), proposed by Xi et al. (2016):

$$
F_{\mathrm{N}_{2} \mathrm{O}}^{15}=F_{\mathrm{N}_{2} \mathrm{O}} \times A_{\mathrm{N}_{2} \mathrm{O}} .
$$

In the above equation, $F_{\mathrm{N}_{2} \mathrm{O}}^{15}$ was the generation rate of ${ }^{15} \mathrm{~N}-\mathrm{N}_{2} \mathrm{O}, \mathrm{mg} /\left(\mathrm{m}^{2} \cdot \mathrm{h}\right), A_{\mathrm{N}_{2} \mathrm{O}}$ was the abundance of ${ }^{15} \mathrm{~N}-\mathrm{N}_{2} \mathrm{O}$, obtained on the samples, $\%$.

$\mathrm{N}_{2} \mathrm{O}$ generation rates from denitrification and nitrification were calculated using formulas (3)-(4) (Xi et al., 2016):

$$
\begin{aligned}
& F_{\mathrm{N}_{2} \mathrm{O}}^{D}=F_{\mathrm{N}_{2} \mathrm{O}}^{15} / F_{n} ; \\
& F_{\mathrm{N}_{2} \mathrm{O}}^{N}=F_{\mathrm{N}_{2} \mathrm{O}}-F_{\mathrm{N}_{2} \mathrm{O}}^{D} .
\end{aligned}
$$

In the above equations, $F_{\mathrm{N}_{2} \mathrm{O}}^{D}$ was the generation rate of $\mathrm{N}_{2} \mathrm{O}$ in denitrification process, $\mathrm{mg} /\left(\mathrm{m}^{2} \cdot \mathrm{h}\right) ; F_{n}$ was the abundance of ${ }^{15} \mathrm{~N}_{-} \mathrm{NO}_{3}{ }^{-}$in the mixed matrix, obtained on the samples, \%; $F_{\mathrm{N}_{2} \mathrm{O}}^{\mathrm{N}}$ was the generation rate of $\mathrm{N}_{2} \mathrm{O}$ in nitrification, $\mathrm{mg} /\left(\mathrm{m}^{2} \cdot \mathrm{h}\right)$.

\section{Results and discussion}

\subsection{The fate of nitrate nitrogen in the influent}

For the SWIS process, nitrate nitrogen $\left(\mathrm{NO}_{3}{ }^{-}\right)$in influent will be discharged, used by microorganisms and converted into gaseous nitrogen (Pan et al., 2016a). In order to quantitatively analyze its fate,nitrate concentration in effluent and soil, $\mathrm{N}_{2} \mathrm{O}$ generation rate, ${ }^{15} \mathrm{~N}$ abundance in soil, effluent and $\mathrm{N}_{2} \mathrm{O}$ were analyzed and calculated (Figure 2). All data was corrected from the background value.

As shown in Figure $2 \mathrm{a}$, at $0 \mathrm{~h}, \mathrm{NO}_{3}{ }^{-} \mathrm{N}$ in the effluent was as low as $(7.5 \pm 1.4) \mathrm{mg} / \mathrm{L}$. Considering that the concentration of $\mathrm{NO}_{3}{ }^{-}-\mathrm{N}$ in the soil was closely related to that in the wastewater (Han et al., 2017), the concentration of soil $\mathrm{NO}_{3}{ }^{-}-\mathrm{N}$ was also low at the beginning (Figure $2 \mathrm{~b}$ ). As the operation progressed, hydraulic load shock was the main reason for the significant increase of $\mathrm{NO}_{3}{ }^{-}-\mathrm{N}$ concentration in both effluent and soil (Lyu et al., 2017). After 5 wetting-drying cycles (amounts to $120 \mathrm{~h}$ ), the concentrations of $\mathrm{NO}_{3}{ }^{-} \mathrm{N}$ in effluent and soil came gradually close to the control groups $(11.6 \pm 0.8 \mathrm{mg} / \mathrm{L}$ and $5.1 \pm 0.3 \mathrm{mg} / \mathrm{kg}$, respectively). As the system was dosed in the 12 hour on12 hour off cycle and then repeated, it was expected to see a nitrate spike at $24-36,48-60,72-84,96-108$ and

a)

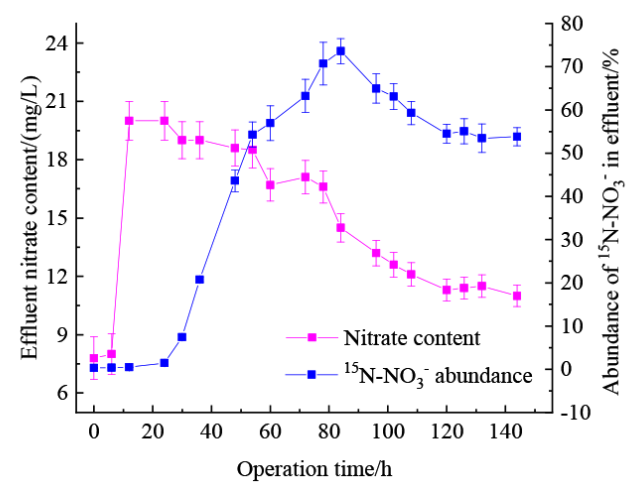

b)

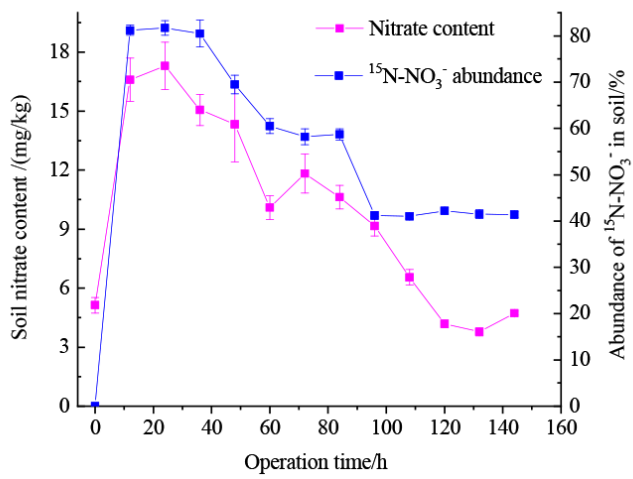

c)

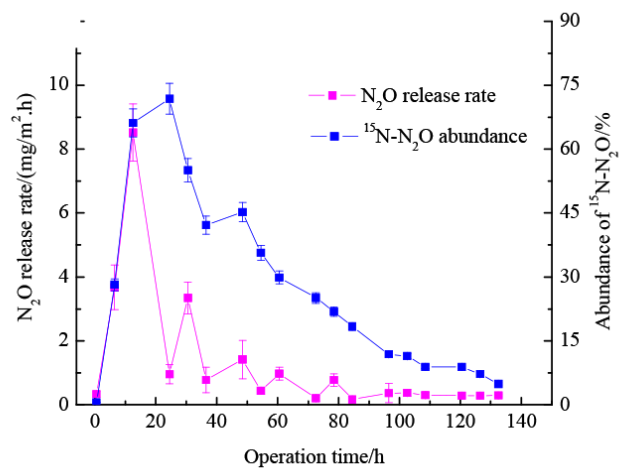

Figure 2. (a) Nitrate concentration and ${ }^{15} \mathrm{~N}-\mathrm{NO}_{3}{ }^{-}$abundance in effluent, (b) Nitrate concentration and ${ }^{15} \mathrm{~N}-\mathrm{NO}_{3}{ }^{-}$abundance in soil and (c) $\mathrm{N}_{2} \mathrm{O}$ release rate and ${ }^{15} \mathrm{~N}-\mathrm{N}_{2} \mathrm{O}$ abundance 
120-132 hours. But an almost continuous decline was found in effluent (Figure 2a). The reason may be that the nitrate in influent was continuously utilized by microorganisms and converted into amino acids and proteins (Pan et al., 2016b; Jiang et al., 2017; Li et al., 2017a). To prove this, organic matter contents of MM were analyzed at 30 , $54,78,102$ and $126 \mathrm{~h}$, respectively. The results showed that during the experimental period, the organic matter content increased slightly from $4.99(0 \mathrm{~h})$ to $5.06(30 \mathrm{~h}), 5.11$ $(54 \mathrm{~h}), 5.12(78 \mathrm{~h}), 5.15(102 \mathrm{~h})$ and $5.19(126 \mathrm{~h})$, indicating that the missing nitrate was likely to be bio-converted into organic substances.

With regard to ${ }^{15} \mathrm{~N}$ abundance, between 0 and $1 \mathrm{~h}$, it was close to $0.366 \%$ of natural abundance in $\mathrm{N}_{2} \mathrm{O}$, indicating that ${ }^{15} \mathrm{NO}_{3}{ }^{-}$didn't participate in the denitrification process within the first $1 \mathrm{~h}$, and even failed to reach the bottom at all. This was mainly due to the special hydraulic flow pattern in the SWIS process, as described in Introduction section. Compared with the sand filtration system and constructed wetlands, the special flow pattern of capillary flow (up-flow) and gravity flow (down-flow) led to the longer retention time and higher removal rate of total nitrogen (Zhang et al., 2015; Han et al., 2017; Maucieri et al., 2017; Li et al., 2018). Consequently, in the early stage of water intake (especially $0-1 \mathrm{~h}$ ), low ${ }^{15} \mathrm{~N}$ abundance was observed in effluent and $\mathrm{N}_{2} \mathrm{O}$. As the water labeled with ${ }^{15} \mathrm{~N}$ gradually reached the outlet, the abundance of effluent ${ }^{15} \mathrm{~N}_{-} \mathrm{NO}_{3}{ }^{-}$, soil ${ }^{15} \mathrm{~N}_{-} \mathrm{NO}_{3}{ }^{-}$and ${ }^{15} \mathrm{~N}-\mathrm{N}_{2} \mathrm{O}$ increased rapidly. After ${ }^{19-20} \mathrm{~h},{ }^{15} \mathrm{~N}_{-} \mathrm{NO}_{3}{ }^{-}$in soil and ${ }^{15} \mathrm{~N}-\mathrm{N}_{2} \mathrm{O}$ reached the maximum, which were $(80.1 \pm 2.2) \%$ and $(74.6 \pm 1.6) \%$, respectively. Since then, ${ }^{15} \mathrm{~N}$ labeled water was discharged gradually from the system. As a result, soil ${ }^{15} \mathrm{~N}_{-} \mathrm{NO}_{3}{ }^{-}$and ${ }^{15} \mathrm{~N}-\mathrm{N}_{2} \mathrm{O}$ decreased and remained at around $(40.2 \pm 2.0) \%$ and $(6.7 \pm 0.6) \%$, respectively. Based on the ${ }^{15} \mathrm{~N}$ isotope tracer experiment, it can be concluded that $(52.3 \pm 1.7) \%$ nitrate in influent was discharged with effluent. Soil microbial utilization and biotransformation accounted for $(40.2 \pm 2.0) \%$. Nitrogen additioncan induce promising effects in the soil by enhancing microbial transformation of native inorganic and organic nitrogen bound (Wu et al., 2017). As a result, the decomposition of labile organic matter in soil was accelerated as indicated by the higher $\mathrm{N}_{2} \mathrm{O}$ emissions.

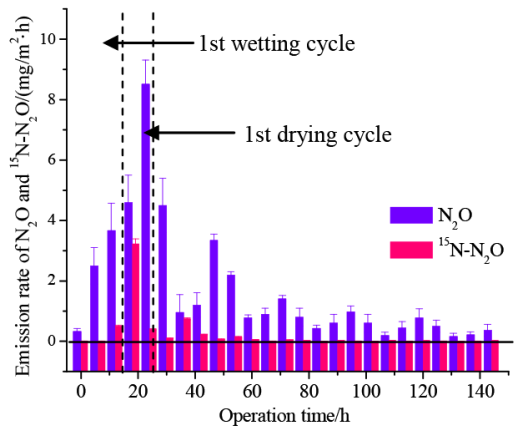

\subsection{Nitrous oxide emissions over time}

Although only a small fraction of influent nitrate was converted to $\mathrm{N}_{2} \mathrm{O}$ through biological denitrification directly, it represented a permanent removal of nitrogen ( $\mathrm{Li}$ et al., 2019). Therefore, after introducing ${ }^{15} \mathrm{~N}, \mathrm{~N}_{2} \mathrm{O}$ and ${ }^{15} \mathrm{~N}$ $\mathrm{N}_{2} \mathrm{O}$ were sampled every 60 min and their emission rates were found to have a linear positive correlation (Figure 3).

The maximum generation rate of $\mathrm{N}_{2} \mathrm{O}$ occurred at the end of the first wetting-drying cycle $(24 \mathrm{~h})$, consistent with the cumulative peak of soil nitrate (as shown in Figure $2 b$ ). Then the generation rate of $\mathrm{N}_{2} \mathrm{O}$ slowed down. The results suggested that soil nitrate concentration was one of the influencing factors of $\mathrm{N}_{2} \mathrm{O}$ generation. Given that nitrate was the electron acceptor in the denitrification process (Sabba et al., 2015), its availability was listed as one of the fundamental prerequisites of $\mathrm{N}_{2} \mathrm{O}$ production. However, the process of denitrification, which basically occurs in the bottom layers where the dissolved oxygen concentration is close to zero, requires the consumption of a relatively large number of organic carbon. The reduction of $1 \mathrm{~g}$ nitrate to $\mathrm{N}_{2}$ needs $2.86 \mathrm{~g}$ BOD (Mander et al., 2014; Sabba et al., 2015). If all nitrates were reduced to $\mathrm{N}_{2} \mathrm{O}$, the demandfororganic carbon would not be much less than the case of $\mathrm{N}_{2}$. Actually, about $60-80 \%$ organics in the influent were removed in the upper layers in the SWIS process (Li et al., 2017b, 2019), resulting in a decrease in $\mathrm{N}_{2} \mathrm{O}$ generation.

Additionally, it is noted that the average generation rate of $\mathrm{N}_{2} \mathrm{O}$ during drying cycles was higher than that in wetting cycles (Figure 3a). For example, during the first wetting cycle $(0-12 \mathrm{~h})$, the $\mathrm{N}_{2} \mathrm{O}$ generation rate was $3.2 \pm$ $0.4 \mathrm{mg} / \mathrm{m}^{2} \cdot \mathrm{h}, 3.4 \pm 0.3 \mathrm{mg} / \mathrm{m}^{2} \cdot \mathrm{h}$ lower than that of the subsequent drying cycle (12-24 h). Due to the increasingly saturated conditions during wetting cycles, $\mathrm{N}_{2} \mathrm{O}$ generated by the denitrification process found it hard to escape from the bottom layer. Instead, during the drying cycles, the unsaturated soil pores encouraged $\mathrm{N}_{2} \mathrm{O}$ to escape. There are three benefits to setting up the drying period of the system. One is that the upper layer of soil has sufficient reoxygenation to help the degradation of organic matter, the other is to help drain the accumulated water in the lower layers, and the third is to encourage the biological metabolic gas (such as $\mathrm{N}_{2} \mathrm{O}$ ) escape from the system

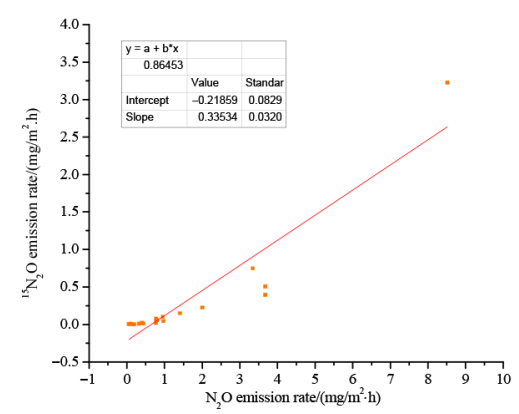

Figure 3. (a) $\mathrm{N}_{2} \mathrm{O}$ and ${ }^{15} \mathrm{~N}-\mathrm{N}_{2} \mathrm{O}$ release rate over time and (b) Linear correlation between $\mathrm{N}_{2} \mathrm{O}$ and ${ }^{15} \mathrm{~N}-\mathrm{N}_{2} \mathrm{O}$ release 
(Zhang et al., 2015; Pan et al., 2016a; Sun et al., 2018; Li et al., 2019). The generation rate of ${ }^{15} \mathrm{~N}-\mathrm{N}_{2} \mathrm{O}$ came close to zero at the beginning $(0-6 \mathrm{~h})$, which had positive correlation with the ${ }^{15} \mathrm{~N}_{-} \mathrm{NO}_{3}{ }^{-}$abundance in soil (as shown in Figure 2b). With extended running time, ${ }^{15} \mathrm{~N}_{-} \mathrm{NO}_{3}{ }^{-}$abundance in soil increased and provided sufficient electron acceptor for denitrification (Ji et al., 2015). Thus, the generation rate of ${ }^{15} \mathrm{~N}-\mathrm{N}_{2} \mathrm{O}$ increased significantly and reached a maximum at $20 \mathrm{~h}$. In brief, $\mathrm{N}_{2} \mathrm{O}$ generation rate was as low as $0.33 \pm 0.1 \mathrm{mg} / \mathrm{m}^{2} \cdot \mathrm{h}$ at the beginning. Its maximum generation was $8.45 \pm 0.8 \mathrm{mg} / \mathrm{m}^{2} \cdot \mathrm{h}$, occurring near the end of the first wetting-drying cycle $(24 \mathrm{~h})$. Then, its generation decreased with increasing running time until it was close to the control group. Furthermore, there was a positive correlation between $\mathrm{N}_{2} \mathrm{O}$ and ${ }^{15} \mathrm{~N}-\mathrm{N}_{2} \mathrm{O}$ generation rate $\left(\mathrm{R}^{2}=0.86\right)$ (Figure $3 \mathrm{~b}$ ).

\subsection{Contribution to nitrous oxide release}

Micro-environmental differentiation of soil profiles can be done by measuring the ORP (Li et al., 2016). The zones with ORP higher than $400 \mathrm{mV}$ and less than $-200 \mathrm{mV}$ are defined as aerobic and anaerobic zones, respectively. While when ORP is between $-200 \mathrm{mV}$ and $400 \mathrm{mV}$, this area is considered to be a facultative zone. Even if a small part of the areas fluctuated between aerobic and facultative or facultative and anaerobic (Figure 4), the upper layer (above $75 \mathrm{~cm}$ ) was in aerobic state, and the lower layer (below $105 \mathrm{~cm}$ ) was soil saturated, which was an anaerobic zone. During nitrification (which occurs in the upper layers), $\mathrm{N}_{2} \mathrm{O}$ can be generated due to the oxidation of $\mathrm{NH}_{4}{ }^{+}-\mathrm{N}$ and hydroxylamine $\left(\mathrm{NH}_{2} \mathrm{OH}\right)$ (Sun et al., 2018). When the dissolved oxygen availability is limited, $\mathrm{NO}_{2}{ }^{-}-\mathrm{N}$ accumulates and exerts toxicity to microbial cells (Domingo-Félez et al., 2017). In this case, heterogeneous nitrite reductase is produced and reduces $\mathrm{NO}_{2}^{-}-\mathrm{N}$ to $\mathrm{N}_{2} \mathrm{O}$ (Zhang et al., 2009; Lyu et al., 2017). Due to the incomplete reduction of $\mathrm{NO}_{2}^{-}-\mathrm{N}$, the denitrification process (which occurs in the lower layers) is another main contributor of $\mathrm{N}_{2} \mathrm{O}$ generation (Kong et al., 2002).

In this study, the source of $\mathrm{N}_{2} \mathrm{O}$ is categorized into denitrification and nitrification processes, namely $F_{\mathrm{N}_{2} \mathrm{O}}^{D}$ and $F_{\mathrm{N}_{2} \mathrm{O}}^{N}$. According to Eq. (3) and (4), $F_{\mathrm{N}_{2} \mathrm{O}}^{D}$ and $F_{\mathrm{N}_{2} \mathrm{O}}^{N}$ were calculated (Figure 5). Due to the lack of nutrients and electron acceptorduring the "rest" period (i.e. the drying period) (Domingo-Félez et al., 2017), $F_{\mathrm{N}_{2} \mathrm{O}}^{D}$ was very low. With the addition of denitrifying substrate and enhanced activity of denitrifying bacteria, $F_{\mathrm{N}_{2} \mathrm{O}}^{D}$ increased to $0.85 \pm 0.1 \mathrm{mg} / \mathrm{m}^{2} \cdot \mathrm{h}$ at $12 \mathrm{~h}$ and reached a maximum of $4.5 \pm 0.5 \mathrm{mg} / \mathrm{m}^{2} \cdot \mathrm{h}$ at $24 \mathrm{~h}$. An increase in the soil nitrate concentration accelerated the denitrification reaction (Pan et al., 2016b; Xi et al., 2016; Wu et al., 2017), leading to an increase in $F_{\mathrm{N}_{2} \mathrm{O}}^{D}$. As a result, when the concentration of nitrate in the soil decreased, decline in $F_{\mathrm{N}_{2} \mathrm{O}}^{D}$ was also noted. Overall, in the first $12 \mathrm{~h}$, nitrification process

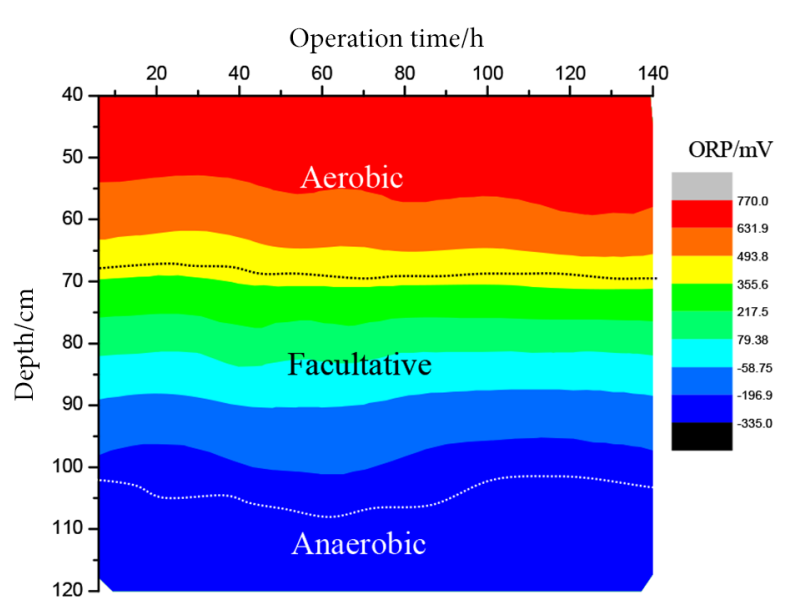

Figure 4. Evolution of ORP versus depth and operation time. ORP profiles were established from five measurements $(40,60$, 80,100 and $120 \mathrm{~cm}$ depth), using spatial linear interpolation
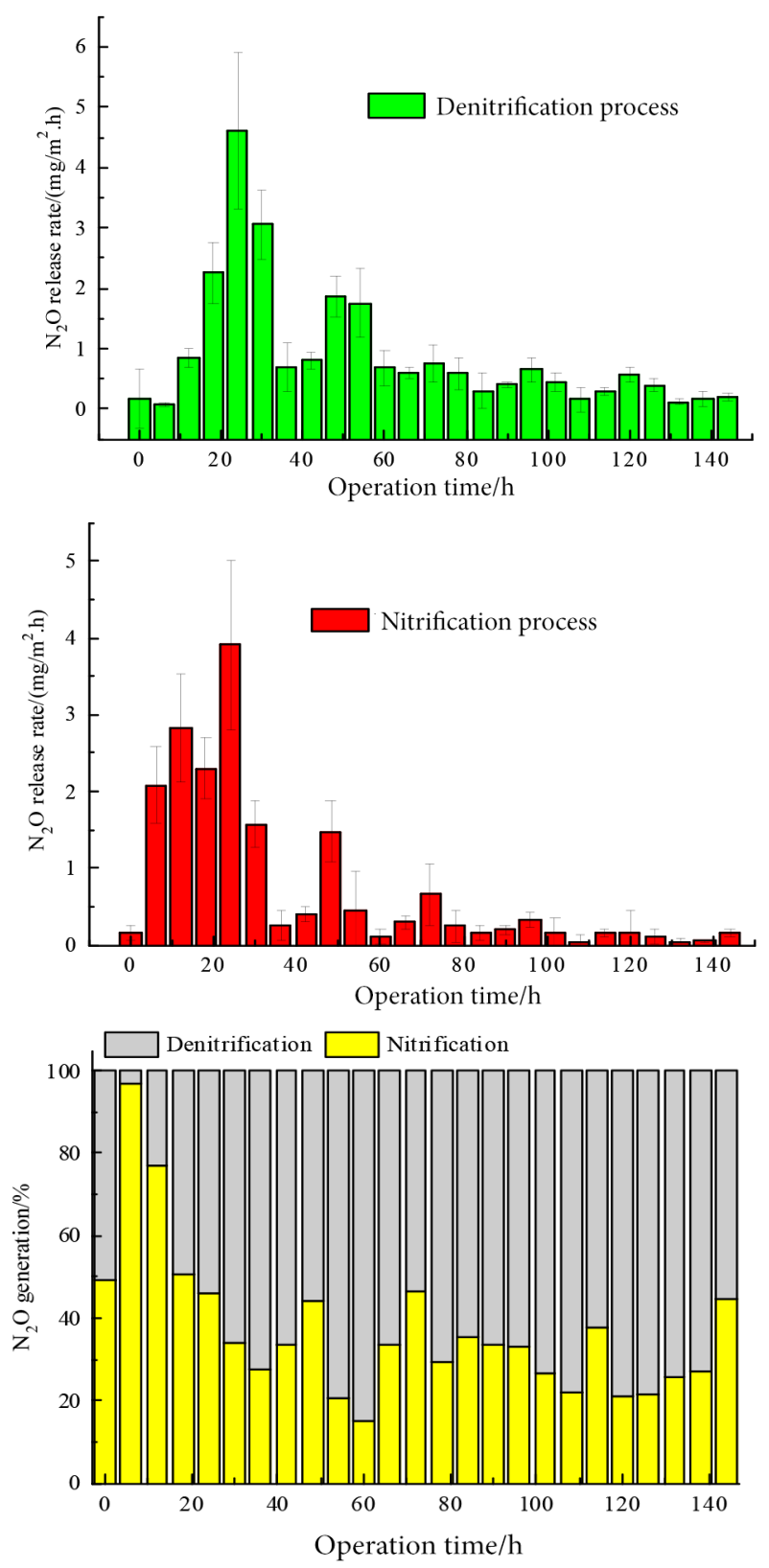

Figure $5 . \mathrm{N}_{2} \mathrm{O}$ produced by nitrification and denitrification 
was the main pathway for $\mathrm{N}_{2} \mathrm{O}$ generation, accounting for $79.6 \pm 2.4 \%$. After $12 \mathrm{~h}, 88.5 \pm 1.3 \%$ of $\mathrm{N}_{2} \mathrm{O}$ was generated from the denitrification.

The experiments provided practical proof that the denitrification process accounted more for $\mathrm{N}_{2} \mathrm{O}$ generation in SWIS processes, especially with the extension of the operation time. The results also indicated that considering the long-term operation of the system, the denitrification process should be given more attention. In view of the mechanism of $\mathrm{N}_{2} \mathrm{O}$ generation during the denitrification process (incomplete reduction of nitrite), it is important to maintain the activity of the related enzymes, such as nitrous oxide reductase. However, SWIS is equivalent to a complex bioreactor, and various microbial processes coexist. Therefore, in addition to the nitrification and denitrification processes, whether and how the other processes contribute to the release of $\mathrm{N}_{2} \mathrm{O}$ needs further research.

\section{Conclusions}

This study revealed the contribution of nitrification and denitrification processes to the release of $\mathrm{N}_{2} \mathrm{O}$ from the SWIS process. After 12 hours of operation, more $\mathrm{N}_{2} \mathrm{O}$ was generated in the lower layer, accounting for $88.5 \pm$ $1.3 \%$. But in the early stage, the aerobic zone (above $75 \mathrm{~cm}$ ) was the place where more $\mathrm{N}_{2} \mathrm{O}$ was generated. Considering the ever-expanding scale of SWIS applications, how to effectively control the release of $\mathrm{N}_{2} \mathrm{O}$ from the denitrification process will become the focus of attention. Furthermore, the amount of $\mathrm{N}_{2} \mathrm{O}$ generated during the drying period was higher than that during the wetting period. And the highest release rate $(8.45 \pm$ $0.8 \mathrm{mg} / \mathrm{m}^{2} \cdot \mathrm{h}$ ) occurred near the end of the first wettingdrying cycle $(24 \mathrm{~h})$. The results suggested that once meeting the effluent requirements, the drying cycle should be shortened as much as possible.

\section{Acknowledgements}

Thanks are due to Dr. Yun-Ting Fang of Institute of Applied Ecology, Chinese Academy of Sciences (Shenyang, China) for assistance with the experiments and valuable discussion. This work was financially supported by the Fundamental Research Funds for the Central Universities [grant number N2001016, N2001012] and the National Natural Science Foundation of China [grant numbers 41571455, 51578115].

\section{Conflict of interest}

The authors declare no conflict of interest.

\section{References}

American Public Health Association (APHA). (2005). Standard methods for the examination of water and wastewater. American Public Health Association/American Water Works Association/Water Environment Federation. Washington, DC.
Domingo-Félez, C., Pellicer-Nàcher, C., Petersen, M. S., Jensen, M. M., Plósz, B. G., \& Smets, B. F. (2017). Heterotrophs are key contributors to nitrous oxide production in activated sludge under low C-to-N ratios during nitrification-batch experiments and modeling. Biotechnology and Bioengineering, 114(1), 132-140. https://doi.org/10.1002/bit.26062

Han, W. J., Shi, M. M., Chang, J., Ren, Y., Xu, R. H., Zhang, C. B., \& Ge, Y. (2017). Plant species diversity reduces $\mathrm{N}_{2} \mathrm{O}$ but not $\mathrm{CH}_{4}$ emissions from constructed wetlands under high nitrogen levels. Environmental Science and Pollution Research, 24, 5938-5948. https://doi.org/10.1007/s11356-016-8288-3

Ji, Q. X., Babbin, A. R., Jayakumar, A., Oleynik, S., \& Ward, B. B. (2015). Nitrous oxide production by nitrification and denitrification in the Eastern Tropical South Pacific oxygen minimum zone. Geophysical Research Letters, 42(24), 1075510764. https://doi.org/10.1002/2015GL066853

Jiang, Y. Y., Sun, Y. F., Pan, J., Qi, S. Y., Chen, Q. Y., \& Tong, D. L. (2017). Nitrogen removal and $\mathrm{N}_{2} \mathrm{O}$ emission in subsurface wastewater infiltration systems with/without intermittent aeration under different organic loading rates. Bioresource Technology, 244(Part 1), 8-14.

https://doi.org/10.1016/j.biortech.2017.07.135

Kong, H. N., Kimochi, Y., Mizuochi, M., Inamori, R., \& Inamori, Y. (2002). Study of the characteristics of $\mathrm{CH}_{4}$ and $\mathrm{N}_{2} \mathrm{O}$ emission and methods of controlling their emission in the soil-trench wastewater treatment process. Science of the Total Environment, 290(1-3), 59-67. https://doi.org/10.1016/S0048-9697(01)01058-0

Li, M., Wu, H. M., Zhang, J., Ngo, H. H., Guo, W. S., \& Kong, Q. (2017a). Nitrogen removal and nitrous oxide emission in surface flow constructed wetlands for treating sewage treatment plant effluent: Effect of C/N ratios. Bioresource Technology, 240, 157-164. https://doi.org/10.1016/j.biortech.2017.02.054

Li, Y. H., Li, H. B., Xu, X. Y., Wang, S. Q., \& Pan, J. (2018). Does carbon-nitrogen ratio affect nitrous oxide emission and spatial distribution in subsurface wastewater infiltration system? Bioresource Technology, 250, 846-852. https://doi.org/10.1016/j.biortech.2017.12.024

Li, Y. H., Li, H. B., Xu, X. Y., Xiao, S. Y., Wang, S. Q., \& Xu, S. C. (2017b). Field study on $\mathrm{N}_{2} \mathrm{O}$ emission from subsurface wastewater infiltration system under variable loading rates and drying-wetting cycles. Water Science and Technology, 76(8), 2158-2167. https://doi.org/10.2166/wst.2017.388

Li, Y. H., Li, H. B., Xu, X. Y., Zhou, Y. C., \& Gong, X. (2016). Correlations between the oxidation-reduction potential characteristics and microorganism activities in the subsurface wastewater infiltration system. Desalination and Water Treatment, 57(12), 5350-5357. https://doi.org/10.1080/19443994.2014.1003606

Li, Y. H., Li, H. B., Yang, L., Xu, X. Y., Wang, S. Q., \& Su, F. (2019). Study on the contribution of different depth layers to $\mathrm{N}_{2} \mathrm{O}$ emission in subsurface wastewater infiltration system. Ecological Engineering, 133, 69-75. https://doi.org/10.1016/j.ecoleng.2019.04.030

Lloréns, M., Pérez-Marín, A. B., Aguilar, M. I., Sáez, J., Ortuño, J. F., \& Meseguer V. F. (2011). Nitrogen transformation in two subsurface infiltration systems at pilot scale. Ecological Engineering, 37(5), 736-743. https://doi.org/10.1016/j.ecoleng.2010.06.033

Lyu, W. L., Huang, L., Xiao, G. Q., \& Chen, Y. S. (2017). Effects of carbon sources and COD/N ratio on $\mathrm{N}_{2} \mathrm{O}$ emissions in subsurface flow constructed wetlands. Bioresource Technology, 245(Part A), 171-181. https://doi.org/10.1016/j.biortech.2017.08.056 
Mander, Ü., Dotro, G., Ebie, Y., Towprayoon, S., Chiemchaisri, C., Nogueira, S. F., Jamsranjav, B., Kasak, K., Truu, J., Tournebize, J., \&Mitsch, W. J. (2014). Greenhouse gas emission in constructed wetlands for wastewater treatment: A review. Ecological Engineering, 66, 19-35. https://doi.org/10.1016/j.ecoleng.2013.12.006

Maucieri, C., Barbera, A. C., Vymazai, J., \& Borin, M. (2017). A review on the main affecting factors of greenhouse gases emission in constructed wetlands. Agricultural and Forest Meteorology, 236, 175-193. https://doi.org/10.1016/j.agrformet.2017.01.006

Pan, J., Yuan, F., Zhang, Y., Huang, L. L., Cheng, F., Zheng, F. P., \& Liu, R. X. (2016a). Nitrogen removal in subsurface wastewater infiltration systems with and without intermittent aeration. Ecological Engineering, 94, 471-477.

https://doi.org/10.1016/j.ecoleng.2016.06.025

Pan, J., Yuan, F., Zhang, Y., Huang, L. L., Yu, L., Zheng, F. P., Cheng, F., \& Zhang, J. D. (2016b). Pollutants removal in subsurface infiltration systems by shunt distributing wastewater with/without intermittent aeration under different shunt ratios. Bioresource Technology, 218, 101-107. https://doi.org/10.1016/j.biortech.2016.06.079

Sabba, F., Picioreanu, C., Pérez, J., \& Nerenberg, R. (2015). Hydroxylamine diffusion can enhance $\mathrm{N}_{2} \mathrm{O}$ emissions in nitrifying biofilms: a modeling study. Environmental Science and Technology, 49(3), 1486-1494.

https://doi.org/10.1021/es5046919
Sun, Y. F., Qi, S. Y., Zheng, F. P., Huang, L. L., Pan, J., Jiang, Y. Y., Hou, W. Y., \& Xiao, L. (2018). Organics removal, nitrogen removal and $\mathrm{N}_{2} \mathrm{O}$ emission in subsurface wastewater infiltration systems amended with/without biochar and sludge. Bioresource Technology, 249, 57-61. https://doi.org/10.1016/j.biortech.2017.10.004

Wu, L., Tang, S. R., He, D. D., Wu, X., Shaaban, M., Wang, M. L., Zhao, J. S., Khan, I., Zheng, X. H., Hu, R. G., \& Horwath, W. R. (2017). Conversion from rice to vegetable production increases $\mathrm{N}_{2} \mathrm{O}$ emission via increased soil organic matter mineralization. Science of the Total Environment, 583, 190-201. https://doi.org/10.1016/j.scitotenv.2017.01.050

Xi, D., Bai, R., Zhang, L. M., \& Fang, Y. T. (2016). Contribution of anammox to nitrogen removal in two temperate forest soils. Applied and Environmental Microbiology, 82, 46024612. https://doi.org/10.1128/AEM.00888-16

Zhang, J. B., Cai, Z. C., Cheng, Y., \& Zhu, T. B. (2009). Denitrification and total nitrogen gas production from forest soils of Eastern China. Soil Biology and Biochemistry, 41(12), 25512557. https://doi.org/10.1016/j.soilbio.2009.09.016

Zhang, L. Y., Ye, Y. B., Wang, L. J., Xi, B. D., Wang, H. Q., \& Li, Y. (2015). Nitrogen removal processes in deep subsurface wastewater infiltration systems. Ecological Engineering, 77, 275-283. https://doi.org/10.1016/j.ecoleng.2015.01.008 